\title{
Economics of Onions Production Using Different Irrigation Water Quality
}

\author{
Heba Yassin Abdel fatah \\ Yehia Mohamed Khalil \\ Karima Awd Mhamed \\ Depantment of Agricultaral Economics, National Research Centre
}

\section{Introduction:}

Egypt is one of the countries that conspicuously have a clear scarcity of natural agricultural resources, especially water supplier. Besides, the agricultural sector is the main consumer of water, which consumes annually about $80 \%$ of the total actual water consumption .water irrigation is the strategic element in agriculture and essential for agricultural expansion. However, the sustainable use of this resource remains questionable, as water efficiency continues to effectively limit future reclamation of land and limits the agricultural sector's ability to achieve high growth rates. The available information indicates that the apparent decrease in the efficiency of water use in Egyptian agriculture is due to two main factors: the increase of water losses through water transport and distribution systems. The efficiency of water transport currently is only $70 \%$, and the second is the obvious decrease in the efficiency of field irrigation systems on average to about $50 \%$, as a result of profusion of water irrigation.

Moreover, Egypt's agricultural drainage water is one of the most important non-conventional water resources for which the state has adopted agricultural development plans. The idea of reuse of agricultural drainage water in irrigation has taken place in water policies since the seventies, and then the establishment of mixing stations of main drainers with main canal water to meet the required expansions in the agricultural area in order to compensate the deficit in the food balance due to the steady increase in the population. This is estimated by about 4.5 billion cubic meters of agricultural drainage water that is used annually (official user). The water policy aims at reaching re-used amounts of agricultural drainage water to about 8.4 billion cubic meters annually by 2017 .

Additionally, onions is one of the most important crops of Egyptian vegetables, with an estimated production of about 2425 thousand tons. The total consumption is about1992 thousand tons. The volume of onions exports is about 433 thousand tons for the average period (2011-2015).

\section{Problem of the Study:}

The problem of this study is that increasing the reclaimed area of agricultural land makes the urgent need for the scarce water element, resulting in the use of agricultural drainage water and mixed water next to the fresh water from the Nile River and wells. The productive and economic efficiency of the Egyptian producers of important agricultural crops such as onions, is not obviously clear except after using different water with the lower quality of fresh water and this water may have bad effects on the health of consumers.

\section{Objective of the Study:}

The research aims at determining the factors affecting the production of onions 


\section{rAr Economics of Onions Production Using Different Irrigation Water Quality}

using different types of water production along with illustrating the production and economic efficiency of onion producers using different types of water is also the examined. .

\section{Research Methodology and Data Sources:}

This research is based on descriptive and quantitative analysis using various measures such as relative importance and averages as well as using the simple regression analysis and Stepwise Regression in more than one mathematical different model, such as linearity and double logarithmic, to determine which one is consistent with economic and statistical logic)., (F) Test is Also used to show whether there is a real difference between onions production using different water or not.

Moreover, the study is based mainly on published and unpublished statistical data from various sources such as the Ministry of Agriculture, Central Agency for Public Mobilization and Statistics, in addition to a random sample of 100 producars of onions crop in Sharkia Governorate using different types of water. The number of onions producers using fresh water is about 25 producers, 25 producers of onions using water wells, 25 producers using drainage water, 25 producers using mixed water an intended manner during 2016.

1-This study is divided into two sections; the first section deals with the study of the most important factors affecting onion production at the national level. The second section deals with the study of onions production functions through using different water and determining the most important factors along with the economic efficiency of these factors.

\section{First: Factors Affecting the Production of Onions at the National Level.}

Through using the amount of onions production during the period (1995-2015), it is clear that it ranged between a minimum rate of 386.4 tons in 1995 and a maximum rate of about 2691.5 in 2015, representing an increase of $14.3596 \%$ from the beginning of the period. In estimating the general time trend equation for the quantity produced during the period of study, the annual increase is found to be statistically significant and estimated at 124.6 thousand tons, representing about $10.1 \%$ of the average quantity of production, which is about 1088 thousand tons. The determining coefficient is 0.92 as shown in the first equation in Table (1).

It is important to mention in this context that while it becomes obviously clear from the study of the productivity of onions from 1995 to 2015, that it ranged between a minimum of about 10per Fadden tons in 1995 and a maximum of about 14.6 tons per Fadden in 2015, representing an increase of about 46\% The general trend of the quantity produced of onions per Fadden during the study period, the annual increase is statistically significant and estimated at 0.241 tons representing about $1.9 \%$ of the average quantity of production of about 12.7 tons. The determining coefficient was 0.92 as shown in the second equation (Table 1)..

As for onion consumption, at the national level the satiation show it was 260,000 tons in 1995 increased to about 2195 thousand tons in 2015, an increase of about $745.8 \%$ during the twe period. The general trend of the quantity produced of onions, during the years 1995 and 2015, (Table 1).. shows an increase of about 110.2 thousand tons about $10.1 \%$ of the average quantity of consumption and about 1088 
thousand tons. The determining coefficient is 0.89 as shown in the third equation in the same table.

Besides, the average price of onions was about 134 pounds in 1995 and about 1041 pounds per ton in 2015 that causes an increase of about $676.8 \%$ from that of the year 1995 . The general time trend of the price of Egyptian onions during the study period has increased annually at 47.1 pounds representing about $9.7 \%$ of the average price raised for the study period by about 486 pounds per ton, which has reached the determining coefficient was 0.88 as shown in the fourth equation(Table 1).

As for costs per Fadden of onions, the data show that it now at from it clear that they range from a about 1528 pounds per Fadden in 1995, and a maximum of about 4397 pounds in 2015, an increase of about 188 percent over the beginning of the period. The general time trend equation for the cost of onions during the study period was at 128.4 pounds that represents about $4.6 \%$ of the average cost of onions for about 2783 pounds per Fadden. The determining coefficient was 0.95 as shown in the fifth equation of the same (Table 1).

As for the ton cost of ton of onions, it is evident that they range from about 115 pounds per ton in 1995 and about 497 pounds in 2015, an increase of about 330 percent over the beginning of the period The general time trend equation for cost per ton of onions during the study period, the statistical annual increase becomes clear and is estimated at 5.99 Egyptian pounds representing about $2.7 \%$ of the average cost of tons of onions, which is about 214 pounds. The determining coefficient is 0.69 as shown in the sixth equation in the same table.

The net revenue of the onions crop during the period (1995-2015), the sassily found that it was between a minimum of 808.6 pounds per Fadden in 1995 and a maximum of 10823 pounds per Fadden in 2015, representing an increase of about 1237 percent over the beginning of the period. The overall mean time of revenue of onions per Fadden during the study period is shown by a statistical increase of 574 pounds per acre representing about $14.2 \%$ of the average acre revenue of about 4033 pounds per acre. The determining coefficient is 0.85 as shown in the seventh equation in table (1)

The net revenue of the cost of the onions crop during the period (1995-2015), is ranged between about 0.53 pounds in 1995 , and about 2.459 pounds in 2015 , an increase of about $364.6 \%$ from the beginning of the period, The general trend of the feddan revenue rate for the costs of onions during the study period is shown by the annual increase in the statistical significance estimated at 0.137 , which represents about $11.3 \%$ of the average of 1.21 . The determining coefficient is 0.79 as shown in the eighth equation in table number (1).

Exports of onions, was about about 116 thousand tons in 1995, increased to about 497 thousand tons in 2015, an increase of about 330\% from the beginning of the period. The general trend of the quantity of exported onions during the study period shows show an annual increase which is estimated at 19.9 thousand tons and representing about $7.3 \%$ of the average. The coefficient determining is 0.79 as shown in the ninth equation.

The export price of onions, is ranged between a minimum of 150 dollar / ton in 1995 and a maximum of 500 dollar / ton in 2015, an increase of $233 \%$ over the 


\section{$r \wedge \leq$ Economics of Onions Production Using Different Irrigation Water Quality}

beginning of the period. The evaluation of the annual increase is estimated at 23.7 dollar / ton representing about $9.4 \%$ of the average export price of onions, which is about 252 dollar per ton. The determining coefficient is 0.69 as shown in the tenth equation in Table (1).

It is concluded from the above that there is a statistically significant increase in the quantity of onions. whil, the consumed quantity has increases. However, the increase in the produced quantity is greater than the consumed. The farm price increases by more than the average cost of the ton. Consequently, the rate of revenue for costs increases along with an increase of the exported onions quantity and the price of export. So, attention should be paid for increasing production while improving the quality characteristics of increasing the exported quantity along with opening new export markets.

Table no. (1) Equations of the General Time Trend of the Main Factors Affecting Onions Production during the Period (1995-2015)

\begin{tabular}{|c|c|c|c|c|}
\hline Number & Variable & Equation & $\mathbf{R} 2$ & $\begin{array}{c}\text { Annual } \\
\text { Changing Rate }\end{array}$ \\
\hline 1 & $\begin{array}{l}\text { Quantity of onions produced } \\
\text { (thousand tons) }\end{array}$ & $\begin{array}{c}\hat{\mathrm{Y}} \mathrm{i}=32.1+124.6 \mathrm{Xi} \\
* *(15)\end{array}$ & 92 & 8.9 \\
\hline 2 & $\begin{array}{l}\text { The average amount of onions } \\
\text { produced per Fadden per ton }\end{array}$ & $\begin{aligned} \hat{\mathrm{Y}} \mathrm{i}= & 10.1+0.241 \mathrm{Xi} \\
& * *(16.6)\end{aligned}$ & 0.94 & 1.9 \\
\hline 3 & $\begin{array}{l}\text { Quantity of onions consumed } \\
\text { (Thousand tons) }\end{array}$ & $\begin{array}{c}\hat{\mathrm{Y}} \mathrm{i}=124+110.2 \mathrm{Xi} \\
* *(15.8)\end{array}$ & 0.89 & 10.1 \\
\hline 4 & $\begin{array}{l}\text { Farm price (Egyptian pound / } \\
\text { ton) }\end{array}$ & $\begin{array}{c}\hat{\mathrm{Y}} \mathrm{i}=32.2+47.1 \mathrm{Xi} \\
* *(12.5)\end{array}$ & 0.88 & 9.7 \\
\hline 5 & $\begin{array}{l}\text { The Fadden cost (Egyptian } \\
\text { pound / acre) }\end{array}$ & $\begin{array}{c}\hat{\mathrm{Y}} \mathrm{i}=1470+128.4 \mathrm{Xi} \\
* *(19.7)\end{array}$ & 0.95 & 4.6 \\
\hline 6 & Ton Cost & $\begin{array}{c}\hat{\mathrm{Y}} \mathrm{i}=148.4+5.9 \mathrm{Xi} \\
* *(12.8)\end{array}$ & 0.90 & 2.7 \\
\hline 7 & The per Fadden revenue & $\begin{array}{c}\hat{\mathrm{Y}} \mathrm{i}=2279+574 \mathrm{Xi} \\
* *(10.6)\end{array}$ & 0.85 & 4033 \\
\hline 8 & Rate Revenue / cost & $\begin{array}{c}\hat{\mathrm{Y}} \mathrm{i}=0.29+0.137 \mathrm{Xi} \\
* *(8.6)\end{array}$ & 0.79 & 11.3 \\
\hline 9 & $\begin{array}{l}\text { Quantity of exports } \\
\text { (Thousand tons) }\end{array}$ & $\begin{array}{c}\hat{\mathrm{Y}} \mathrm{i}=53.8+19.9 \mathrm{Xi} \\
* *(8.5)\end{array}$ & 0.79 & 7.3 \\
\hline 10 & Export price (Dollar / Ton) & $\begin{array}{c}\hat{\mathrm{Y}} \mathrm{i}=8.6+23.7 \mathrm{Xi} \\
* *(6.4)\end{array}$ & 00.69 & 9.4 \\
\hline
\end{tabular}

Since $\hat{Y} i$ indicates the estimated value of the dependent variable and $X i$ refers to the element of time as an independent variable since $i(1,2,3,4$..... 21).

** Significant at the level of $1 \%$. * Significant at the level of $5 \%$.

Source: Ministry of Agriculture and Land Reclamation, Economic Affairs Sector, Agricultural Economics Publications, Miscellaneous Editions.

Second: Studying the Relationship between the Produced Quantity of Onions and the Combined Influencing Factors

Table (2) shows that the dependent variable is the amount of onions (Y $i$ ). The independent factors are :( Xi1) the quantity of seedlings (one thousand seedlings), (Xi2) the quantity of mechanical work by hours(hour/fadden)., (Xi3) the quantity of human labor ( $\operatorname{man} /$ day/work), (Xi4)quantity of nitrogenous fertilizers the number of 
active units , (Xi5) the pesticides value L .E, (Xi6)quantity of irrigation water $\mathrm{m} 3$. Initially, the correlation matrix is worked out to determine whether there are problems with estimation or not through using some mathematical models. Estimating the function in linear and double logarithmic way through using the Multiple Regression Analysis and then using the Stepwise Regression Analysis in order to reach the most important factors affecting the amount of production of onions through using different water and obtain the best models whose results correspond to the economic and statistical logic.

In the case of studying onions producers who use fresh water, as shown in Table (3), the results of the estimation illustrated the preference of the double logarithmic model mentioned in the table indicated that the statistical significance of the element of the quantity of seedling, human labor and irrigation water. On the hypothesis of providing the conditions of the least squares, the increase of seedling is (1\%) with the stability of the other elements as it is. Yet, the increased onions production leads to a significant increase of $0.023 \%$. As for the human labor, the valued flexibility from the function has been significantly proven. Thus, the increase in the quantity of human labor by $1 \%$ leads to an increase in the quantity of onions produced by fresh water with a significant increase of about $0.130 \%$. As for water quantity, the increase in water quantity by $1 \%$ leads to a significant increase in the quantity of onions by about $0.813 \%$. The total elasticity confirms that by increasing the previous elements together by $1 \%$, it leads to an increase of the losses by $0.966 \%$. This means that the onions producers and the users of fresh water produced in the economic stage. Also, the determining coefficient (R 2), which amounted to about 0.79 , refers to the fact that the former elements are responsible for the interpretation of about $79 \%$ of the total change in the production of onions. Therefore, the significance of the model has been confirmed as the value of $(\mathrm{F})$ is calculated at about 29.7, which confirms the significance of this model.

As for the production of onions through using ground water, the statistical significance of the elasticity of the human labor quantity, the quantity of fertilizer and the quantity of irrigation water are determined. In addition, even if the conditions of the small squares method are provided in the estimation, the increase in human labor by $1 \%$ led to an increase in the amount of onions produced by using the well water this is a significant increased by $0.02 \% 0.143 \%$. As for the nitrate fertilizer element, the increase of the element by $1 \%$ with the stability of the other elements as they are, led to a significant increase of the quantity of onions produced that reached about $0.143 \%$. Concerning of the quantity of water, the increase in the quantity of water by $1 \%$ led to a significant increase in the quantity of onions that reached about $0.818 \%$. In terms of the value of pesticides, it is showed that there is an opposite trend. The increase in the value of pesticides by $1 \%$ led to an amount of onions quantity of about $0.153 \%$. The total elasticity confirms that by increasing the previous combined elements by $1 \%$, the losses are increased by $0.963 \%$, which means that the onions producers of onions who use fresh water produced in the economic stage. Besides, the value of the coefficient of determination (R2), which amounted to about 0.82 , refers to that the previous elements are responsible for the interpretation of about 


\section{r^ Economics of Onions Production Using Different Irrigation Water Quality}

$82 \%$ of the total change in the production of onions. Also, the significance of the model has been confirmed where the estimated value of (F) calculated by about 28.4.

In the case of onions production through using agricultural drainage water, the statistical significance of the facilities of the human labor quantity and the quantity of irrigation water has been proven. Therefore, the increase in the quantity of human labor by $1 \%$ leads to a statistical increase reached about 0.607 .

As for water quantity, the estimated flexibility of a statistical function has been proven leads to increasing the quantity of water by $1 \%$ that also leads to an increase in the quantity of onions, a significant increase of about $0.502 \%$. The total elasticity confirms that the increase of the former elements combined by $1 \%$ and increases the production of onions by $1.11 \%$ which means that the producers and those who use agricultural drainage water in the production of onions produced in the non-economic stage. Besides, the value of the coefficient of determination (R 2), which amounted to about 0.77 , illustrated that the previous elements are responsible for the interpretation of about $77 \%$ of the total change of onions production. Thus, the significance of the model is confirmed where the value of (F) is calculated at about 69.3.

Table (2) Stepwise Regression of Onions Production through Using Different Water quantity in the Study Sample

\begin{tabular}{|c|c|c|c|c|}
\hline Statement & $\begin{array}{l}\text { Mathematical } \\
\text { Image }\end{array}$ & Equation & $\mathbf{R}^{2}$ & $\mathbf{F}$ \\
\hline \multirow{2}{*}{$\begin{array}{c}\text { Through } \\
\text { using fresh } \\
\text { water in } \\
\text { agriculture }\end{array}$} & Linear & $\begin{array}{c}\hat{\mathrm{Y}} \mathrm{i}=4.2+1.65 \mathrm{Xi}_{1}+0.062 \mathrm{Xi}_{3}+0.018 \mathrm{Xi} 4+0.002 \mathrm{Xi} 6 \\
* *(3.9) \quad * *(4.1) \quad *(2.5) \quad * *(2.98)\end{array}$ & 0.71 & 20.8 \\
\hline & Logarithmic & 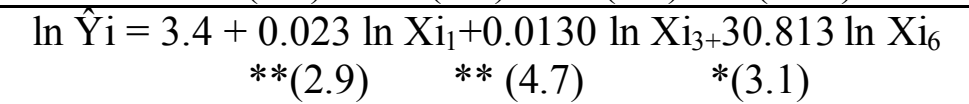 & 0.79 & 29.7 \\
\hline \multirow{2}{*}{$\begin{array}{c}\text { Through } \\
\text { using water } \\
\text { ground in } \\
\text { agriculture }\end{array}$} & Linear & $\begin{array}{c}\hat{\mathrm{Y}} \mathrm{i}=1.7+0.121 \mathrm{Xi}_{3}+0.017 \mathrm{Xi} 4-0.94 \mathrm{Xi5}+0.006 \mathrm{Xi} 6 \\
*(2.5) * *(2.6) * *(2.8) * *(2.7)\end{array}$ & 0.73 & 10.3 \\
\hline & Logarithmic & 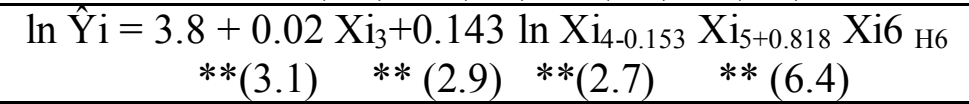 & 0.82 & 28.4 \\
\hline \multirow{4}{*}{$\begin{array}{c}\text { Through } \\
\text { using } \\
\text { drainage } \\
\text { water in } \\
\text { agriculture } \\
\text { Through } \\
\text { using mixed } \\
\text { water in } \\
\text { agriculture }\end{array}$} & Linear & $\begin{array}{c}\hat{\mathrm{Y}} \mathrm{i}=11.9+0.063 \mathrm{Xi}_{3}-0.077 \mathrm{Xi}_{5}+0.51 \mathrm{Xi6} \\
* *(5.16) * *(3.94) \quad * *(2.8)\end{array}$ & 0.76 & 56.8 \\
\hline & Logarithmic & $\begin{array}{c}\ln \hat{\mathrm{Y}} \mathrm{i}=0.93+0.607 \ln \mathrm{Xi}_{3}+0.0502 \ln \mathrm{Xi}_{6} \\
* *(5.6) \quad * *(3.2)\end{array}$ & 0.77 & 69.3 \\
\hline & Linear & $\begin{aligned} \hat{\mathrm{Y}} \mathrm{i} & =0.93+0.022 \mathrm{Xi}_{2}+0.0+0.007 \mathrm{Xi}_{6} \\
& * *(3.7) *(2.7) * *(5.6) * *(3.7)\end{aligned}$ & 0.80 & 71.9 \\
\hline & Logarithmic & 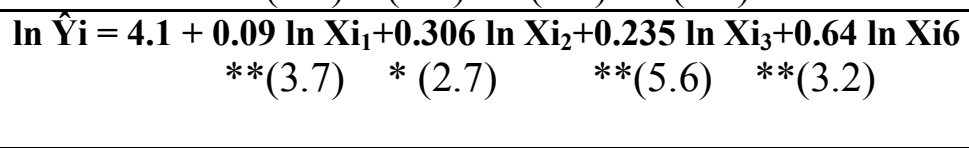 & 0.83 & 85.3 \\
\hline
\end{tabular}

Where $\hat{\mathbf{Y}} \mathbf{i}=$ the quantity of onions production estimated per ton.

$X i_{1}=$ the estimated of seeds by seedlings.

$\mathrm{Xi}_{2}=$ the quantity of mechanical work by hours(hour/fadden).

$\mathrm{Xi}_{3}=$ the quantity of human labor ( $\mathrm{man} / . \mathrm{day} /$ work).

$\mathrm{Xi}_{4}=$ the amount of nitrates per Fadden(the number of active units)

$\mathrm{Xi}_{5}=$ the pesticides value $(\mathrm{L.E})$

$\mathrm{Xi}_{6}=$ the quantity of irrigation water $\left(\mathrm{m}^{3}\right)$.

$i=1,2,3$, number of farmers in the area. $* *$ Significant at the level of $0.01 *$ significant at the level of 0.05

Source: Computed from the questionnaire forms for the sample of the study in Sharkia Governorate in 2016. 
Moreover, it is clear from the equations in table (3) that the production of onions through using mixed water is affected by the elements of seedling, human labor and the quantity of irrigation water. Therefore, increasing the seedling element by $1 \%$, assuming other things being equal, leads to a significant increase in the amount of onions production reached about $0.09 \%$. As for the mechanical work that increased by $1 \%$ led to a significant increase in the quantity of produced onions by fresh water by about $0.306 \%$. in terms of the for human work, the increase in the quantity of human labor by $1 \%$, leads to a significant increase of produced onions through using the mixed water that reached about $0.235 \%$. With regard to the quantity of water, the increase in the quantity of water by $1 \%$, leads to a significant increase of the quantity of onions, of about $0.64 \%$. The total elasticity asserts that by increasing the previous affecting elements combined together reached about $1 \%$. It also leads to an increase in the losses by about $1.2 \%$ which means that the producers of onions and users of fresh water produced in the non-economic stage. Besides, the value of the coefficient of determination (R2), which amounted about 0.83 , refers to the previous elements as responsible for the interpretation of about $83 \%$ of the total change in the production of onions through using mixed water. Therefore, the significance of the model is estimated since the value of (F) calculated by about 85.3 , which also confirmed the significance of the model.

\section{The Economic Efficiency of the Factors Affecting the Production of Onions using Different water quantity.}

Table (3) shows that the most important factors affecting the production of onions through using fresh water are the quantity of seedlings, the quantity of human labor, the quantity of water in order to reach efficiency, which shows that the value of the marginal output is greater than the price of the input. That the value of the marginal output is 1.16 Egyptian pounds compared to the value of water that estimated by about 0.55 Egyptian pounds. The economic efficiency of the seedling and human labor element is not efficieny. It becomes obviously clear that the most important factors affecting production of onions through using ground water are the quantity of human labor, the amount of nitrate fertilizer and the quantity irrigation water. The marginal output value amounted to about 1.03 Egyptian pounds and the value of water estimated by about 0.55 pounds. As for the most important factors affecting production of onions through using agricultural drainage, it is found that human work and amount water are the most important factors. Besides, the efficiency of the water element is confirmed where the value of the marginal output reached about 0.77 pounds and the value of water element is 0.45 pounds, while it is found that the most important factors affecting the production of onions The use of mixed water is the amount of seedlings, mechanical work, human labor, irrigation water quantity and economic efficiency of the water element. This confirms the importance of the water element in the production. Despite the efficiency of the water element in the case of using different water, yet fresh water and well water are more efficient than other kinds of water as shown from table number (3). 
$r \wedge \wedge$ Economics of Onions Production Using Different Irrigation Water Quality

Table (3) Economic Efficiency of the Factors Affecting Production of Onions through Using Different Water types in the Sample of the Study

\begin{tabular}{|c|c|c|c|c|c|c|c|}
\hline $\begin{array}{c}\text { Type of } \\
\text { water } \\
\text { used } \\
\end{array}$ & Economic Efficiency & Seedlings & $\begin{array}{c}\text { machine } \\
\text { Labor }\end{array}$ & $\begin{array}{c}\text { Human } \\
\text { Labor }\end{array}$ & $\begin{array}{c}\text { Nitrate } \\
\text { Fertilizer }\end{array}$ & $\begin{array}{c}\text { Value of } \\
\text { Pesticides }\end{array}$ & $\begin{array}{c}\text { Amount } \\
\text { of } \\
\text { Water }\end{array}$ \\
\hline \multirow{4}{*}{$\begin{array}{l}\text { Fresh } \\
\text { water }\end{array}$} & Quantity of factor & 1.6 & & 3.7 & & & 7.5 \\
\hline & Marginal Output & .694 & & 0.29 & & & 0.928 \\
\hline & Marginal Output Value & 0.868 & & 037 & & & 1.16 \\
\hline & Element Price & 15 & & 80 & & & 0.55 \\
\hline \multirow{4}{*}{$\begin{array}{l}\text { Ground } \\
\text { water }\end{array}$} & Quantity of factor & & & 3.3 & 4.9 & & 7.6 \\
\hline & Marginal Output & & & 0.05 & 0.263 & & 1.02 \\
\hline & Marginal Output Value & & & 0.07 & 0.328 & & 1.03 \\
\hline & Element Price & & & 80 & 3.5 & & 0.55 \\
\hline \multirow{4}{*}{$\begin{array}{c}\text { Drainage } \\
\text { water }\end{array}$} & Quantity of factor & & & 3.1 & & & 7.7 \\
\hline & Marginal Output & & & 1.87 & & & 0.61 \\
\hline & Marginal Output Value & & & 2.34 & & & 0.77 \\
\hline & Element Price & & & 80 & & & 45 \\
\hline \multirow{4}{*}{$\begin{array}{l}\text { Mixed } \\
\text { water }\end{array}$} & Quantity of factor & 1.9 & 3.1 & 2.7 & & & 7.5 \\
\hline & Marginal Output & 0.452 & 0596 & 0.82 & & & 0.81 \\
\hline & Marginal Output Value & 0.566 & 1.19 & 1.028 & & & 1.01 \\
\hline & Element Price & 15 & 50 & 80 & & & .45 \\
\hline
\end{tabular}

Source: collected and calculated from the sample data of the study in Sharkia governorate in 2016.

\section{CONCLUSION :}

it is clear from the production functions that the most important factors affecting the production of onions are the amount of seedlings, the amount of human labor, the amount of machine work, the amount of nitrate and the amount of irrigation water, therefore these factors should be taken into account by improving the quality of seedlings through using modern technologies of varieties and rationalizing the use of other factors along with trying to rotate irrigation water for current conditions where there is scarcity in water element as well as improving its quality. Besides, economic and productive efficiency have confirmed that the water element is the only element that has the value of the marginal output that is greater than the price of the source. The preference of fresh water and wells for onions producers is also asserted. Therefore, it is highly important to pay attention for improving the quality of agricultural drainage water and mixed water in order to increase the production of onions that has good natural qualities and good for export.

\section{Summary:}

Egypt's agricultural drainage water is important as non-conventional water resources upon which the state has adopted agricultural development plans. The idea of reusing agricultural drainage water in irrigation has taken a place in water policies since the seventies, the establishment of mixing main stations of water drainage with the water of other main canal in order to meet the required expansions in the agricultural area to fill the shortage in the food balance due to the steady increase in the population. The utilized of agricultural drainage water is estimated by about 4.5 billion cubic meters annually (officially used). The water policy aims to reach the 
quantities of reused agricultural drainage water to about 8.4 billion cubic meters annually by 2017 .

Onions is one of the most important Egyptian vegetable crops, which production is estimated by about 2425 thousand tons. The total consumption is about 1992 thousand tons. The amount of onions exports is about 433 thousand tons. This is the average of the period (2011-2015).the problem of the study is that the productive and economic efficiency of the producers of the exporting important Egyptian agricultural crops is not clear such as onions through using different water that is less quality than fresh water, and this type of water may harm the health of consumers.

The study aims at determining the factors affecting the production of onions through using different water and the extent of the effect of each of these factors on production and illustrating the productive and economic efficiency of the producers who use different types of water in the irrigation of onions crop as well as studying the indicators that show the efficiency of onions production through using different water. the data are collected from a sample of 100 farmer of onions producers in Sharkia governorate along with data from the Ministry of Agriculture.

The study of the factors affecting the onions production show that there is an increase in the quantity of onion produced; a statistically significant increase. In contrast, the consumed quantity has also increased. Yet, the increase in the quantity produced is greater than the consumed one and the farm price increases by more than the average cost per ton. Thus, the cost revenue rate also increases as well as the exported amount of onions and the exporting price along with opening new exporting markets. Therefore, attention should be paid to increasing production while improving the qualitative characteristics of increasing the quantity exported with the opening of new export markets.

Besides, the production functions of the onions show that the most important affecting factors in producing onions are the amount of seedlings, the amount of human labor and the amount of machine work, the amount of nitrates and the amount of water of irrigation. Consequently, attention should be paid to these factors by improving the quality of seedlings through using modern technologies of varieties and rationalize the use of other factors while trying to rotate water of irrigation to the current conditions where there is a scarcity in the element of water along with improving their quality. In addition, the productive and economic efficiency confirmed that the water element is the only element that has the value of the marginal output is greater than the price of the imported along with the preference of fresh water and wells for onions producers. Therefore, attention should be paid to improve agricultural drainage water and mixed water in order to increase the production of onions that has good natural qualities and good for export.

\section{References:}

1- Ministry of Water Resources and Irrigation in 2010-Strategy for Management and Development of Water Resources in Egypt till 2050.

2- Al-ashmawy Khairi Hamed \& Others. "An Economic Study on Mixing of Agricultural Drainage Water in Irrigation of Lands". The Final Report of the Internal Project No. 5/117/10. National Research Center, June 2004. 


\section{rq. Economics of Onions Production Using Different Irrigation Water Quality}

3- Salah. Sayed Saleh Sayed(1999): The Economic Effects of Mixing Drainage Water with Irrigation Water in Fayoum Governorate. The Final Report of the National Councils for Research and Agricultural Extention, Agricultural Research Center, Department of Agricultural Economics, Cairo University, Fayoum Branch.

4- Amer Mohamed Hassan, Mohamed Ahmed Abdel Khalek: Reusing Agricultural Drainage Water, Ministry of Water Resources and Irrigation, General Authority for Drainage Projects, Agricultural Drainage Manual, First Edition, February 2003.

(الملخص:

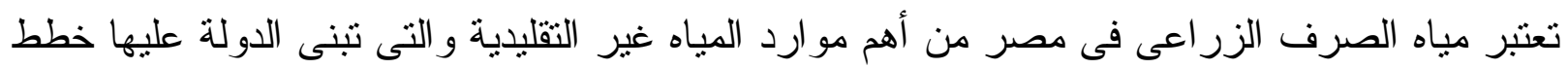

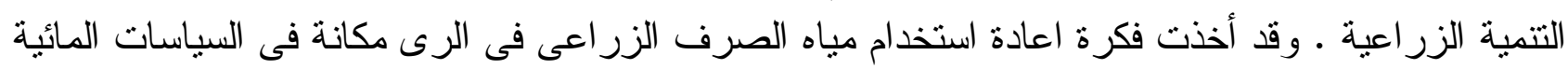

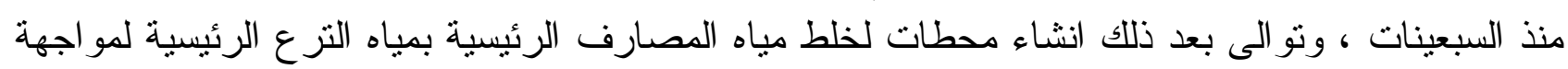

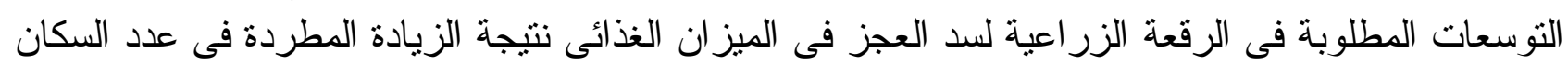

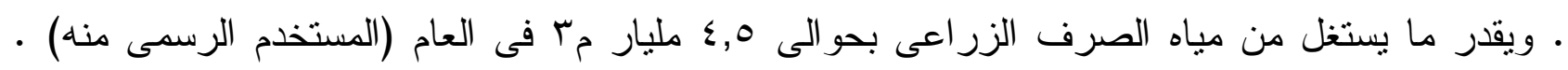

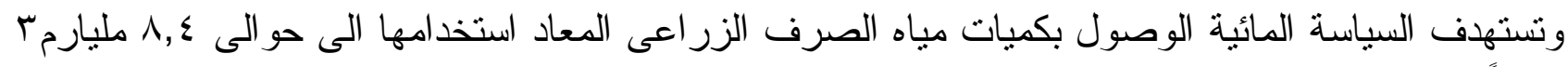

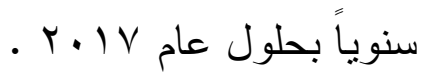

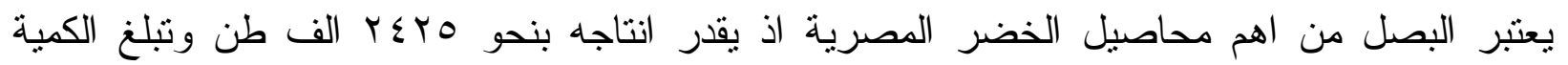

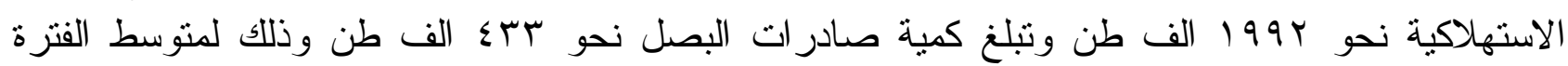

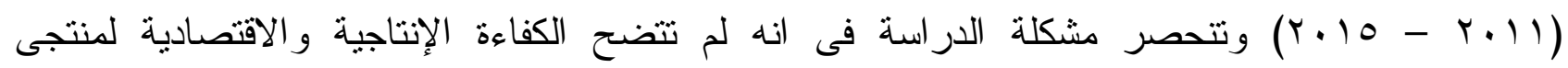

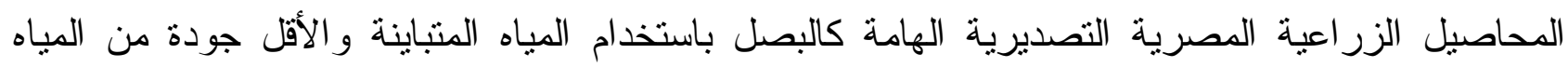

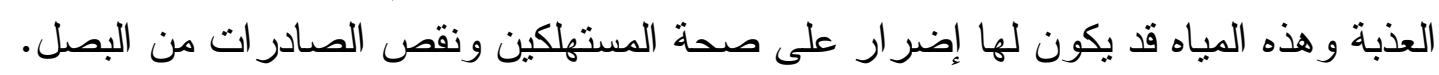

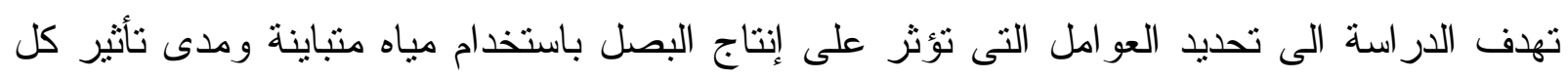

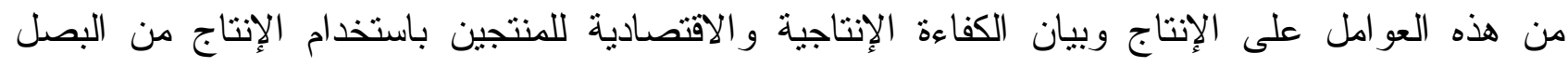

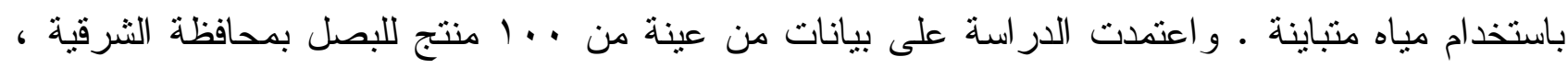

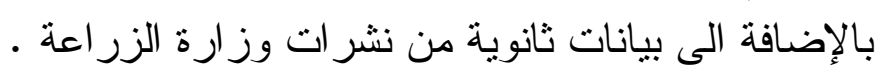

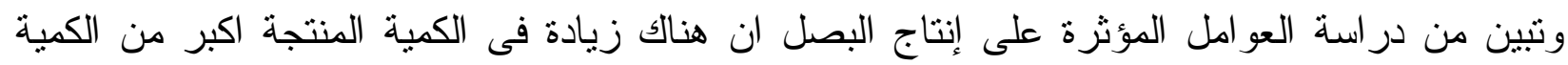

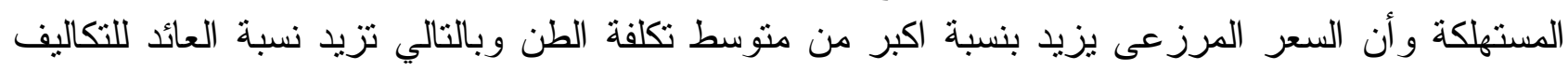

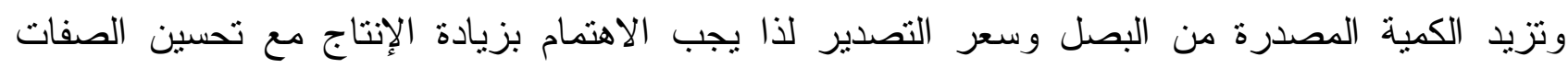

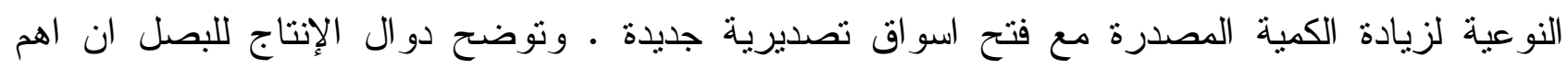

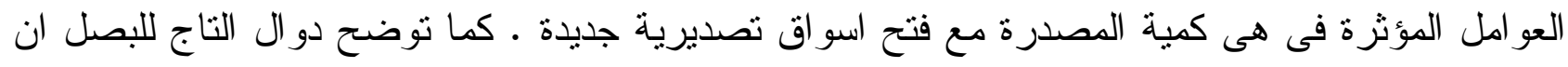

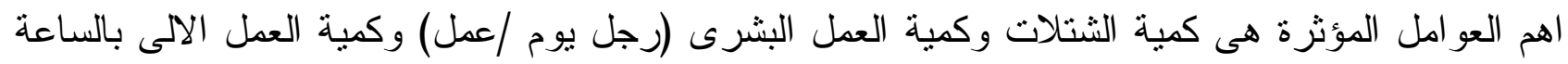

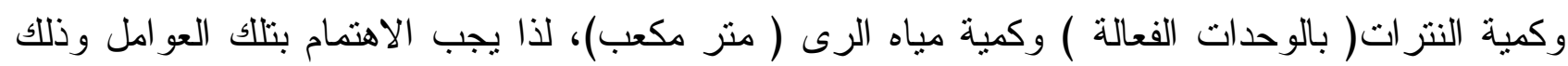

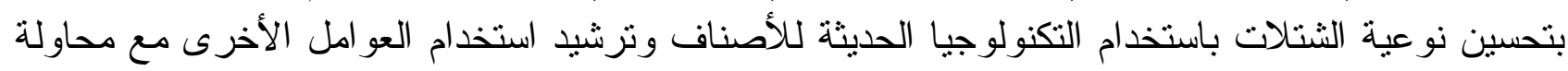

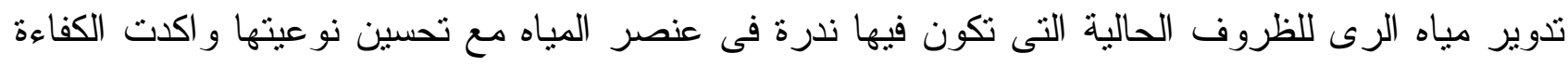

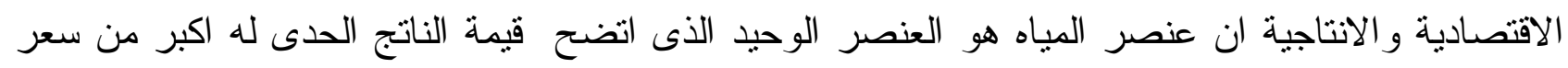

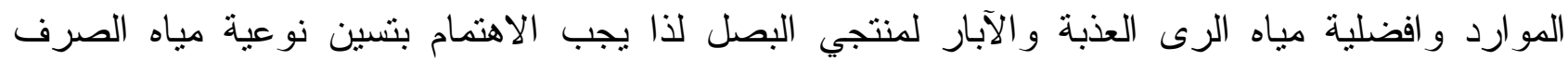

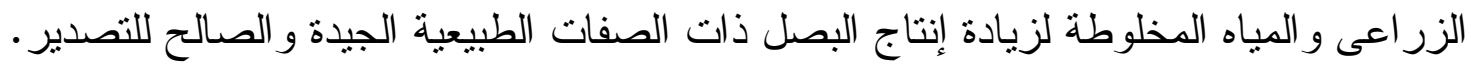

